\title{
The impact of university teacher training on prospective teachers' CK and PCK - a comparison between Austria and Germany
}

Sabine Fritsch ${ }^{1 *}$, Stefanie Berger ${ }^{1}$, Jürgen Seifried ${ }^{1}$, Franziska Bouley ${ }^{2}$, Eveline Wuttke ${ }^{2}$, Kathleen Schnick-Vollmer ${ }^{3}$ and Bernhard Schmitz ${ }^{3}$

* Correspondence:

fritsch@bwl.uni-mannheim.de

${ }^{1}$ Chair of Economic and Business

Education II, University of

Mannheim, L4,1, D-68161

Mannheim, Germany

Full list of author information is

available at the end of the article

\begin{abstract}
Background: As teacher training plays a major role in the development of (prospective) teachers' knowledge, differences between the professional knowledge of prospective teachers at Austrian and German universities were examined in the current study. The teacher training systems of business and economic education in both countries differ substantially regarding structure and content. The German system consists of two consecutive phases with different foci (university education with an emphasis on theories and domain-specific knowledge, followed by school-based practical training with the objective of acquiring practical experience). Thus, in Germany, opportunities to learn (OTL) mainly cover domain-specific knowledge with less focus on didactics and teaching experience. In contrast, Austrian universities offer an integrated approach that combines the two phases (i.e., theoretical input and practical teaching experiences are closely linked) at the university level.
\end{abstract}

Methods: A paper-and-pencil test was used to measure content knowledge (CK) and pedagogical content knowledge (PCK) in the domain of accounting of prospective teachers in Germany and Austria. The total sample consists of $n=1,401$ prospective teachers from German and Austrian universities. Taking the structural differences in teacher education into account, differences in CK and PCK between German and Austrian prospective teachers were expected.

Results and conclusions: Accordingly, the results show that the Austrian sample outperformed the German one. In addition, for both the German and the Austrian sample, university-based OTL in accounting had a crucial impact on the CK score. Concerning PCK, however, the situation is different: none of the university-based OTL had an impact on Austrian prospective teachers' PCK, and only small effects were found for the German sample. Possible reasons for the unexpected findings are discussed.

Keywords: Teacher training; Business and economic education; Content knowledge; Pedagogical content knowledge; Comparative study

\section{Background}

Current research on teaching and instruction highlights the significance of teacher qualification for learner achievement. It is assumed that teachers' competencies (e.g., choosing appropriate representations and explanations or providing challenging tasks) have a crucial impact on students' learning processes (Hattie 2009; Kunter et al. 2013; 
Lipowsky et al. 2009). Various studies provide evidence for the relevance of teachers' domain-specific professional knowledge, namely their content knowledge (CK) and pedagogical content knowledge (PCK) (Baumert et al. 2010; Hill et al. 2005). Therefore, current research efforts focus on the development of prospective teachers' competencies during higher education. Empirical findings are available first and foremost for the domain of mathematics (Blömeke et al. 2008a; Kleickmann and Anders 2013). In addition, initial findings in the natural sciences (Riese and Reinhold 2012, Schmelzing et al. 2013), English and German (Blömeke et al. 2011), and business and economics (Kuhn et al. 2014) are noteworthy. However, domainspecific models of teachers' competencies, as well as competence measurement instruments are still lacking (Blömeke et al. 2013; Schmelzing et al. 2013).

Furthermore, there is still a need for empirical evidence with regard to the impact that opportunities to learn (OTL) during teacher training have on teachers' competencies (Cochran-Smith 2005; see also Blömeke et al. 2012; Kleickmann and Anders 2013). This is also true for prospective teachers in business and economic education. Therefore, the research project KoMeWP a aims to contribute to this field of research and provide insights into prospective business and economics teachers' competencies and their OTL. To do so, a paper-and-pencil test to measure the CK and PCK of prospective teachers at vocational schools in Germany, as well as their beliefs and self-regulation skills, was developed (see Berger et al. 2013; in press). Moreover, prospective teachers' educational background characteristics, especially their OTL during both university education and prior to university education were analysed, as those variables were expected to foster the development of CK and PCK. The test instruments focus on the domain of accounting since this area is from a learning perspective - crucial for a comprehensive understanding of business contexts (Seifried 2012). Therefore, teachers' competencies in this area are of special interest.

The current paper examines the professional knowledge (CK and PCK) of prospective teachers at Austrian and German universities, as well as the impact of OTL on CK and PCK. In doing so, special attention is paid to a comparison between prospective teachers from Germany and Austria, as teacher training for vocational schools differs substantially between both countries. In Germany, teacher training is organised in two consecutive phases (i.e., university education with a main emphasis on theories and domain-specific knowledge and school-based practical training with the objective of acquisition of practical experience), while Austria runs an integrated approach (i.e., integration of theoretical and practical education at the university level). Based on this background, differences in prospective teachers' CK and PCK are expected.

The article is structured as follows: an overview of current studies on teachers' CK and PCK and their impact on students' learning processes will be given, and empirical evidence on the relationship of OTL and (prospective) teachers' CK and PCK will be presented. Furthermore, the teacher training systems in Germany and Austria will be outlined. Based on this, a description of the study design and sample will be given, and the results of the test performance of prospective teachers at Austrian and German universities will be reported. Finally, a discussion and an outlook section will summarise and reflect central results. 


\section{Teachers' content knowledge and pedagogical content knowledge}

The conceptualisation of teachers' professional knowledge was introduced by Shulman (1986) who differentiated - among other components - between content knowledge (CK), pedagogical knowledge (PK), and pedagogical content knowledge (PCK). Meanwhile, there is a growing body of research on teachers' knowledge base, especially on teachers' PCK. Current studies provide evidence that teachers' domainrelated knowledge significantly affects teaching quality, and - subsequently - student achievement (Hattie 2009; Hill et al. 2005). In the German research project COACTIV (“Cognitive Activation in the Classroom”; see Kunter et al. 2013) teachers' CK, and mainly PCK, were found to foster student progress in mathematics significantly (Baumert et al. 2010).

A common conceptualisation of this construct does not exist so far (an overview of different conceptualisations was given by Schmelzing et al. 2013), but knowledge of students' conceptions and knowledge of multiple representation and explanations (both identified by Shulman 1986), could be seen as prevalent facets. While some studies focus on these two facets (e.g., Jüttner and Neuhaus 2012), others consider additional ones such as goals and purposes of teaching (e.g., Rohaan et al. 2009), curriculum aspects (e.g., Geddis 1993), the use of media (e.g., Marks 1990), or knowledge of tasks as instructional tools (e.g., Krauss et al. 2013).

There is empirical evidence supporting Shulman's (1986) assumption that CK and PCK are two correlated but separable constructs (Krauss et al. 2008; for a critical discussion, see Neuweg 2014). Correlation coefficients vary between different domains. For mathematics or physical science, latent correlations up to $r=.81$ are found (Blömeke et al. 2008b; Krauss et al. 2013; Riese and Reinhold 2012); in less structured domains (e.g., English or German) lower latent correlations are reported ( $r=.40$ to $r=.60$; Blömeke et al. 2011). In business and economic education, CK and PCK correlate (in terms of manifest correlation) at $r=.35$ for business administration and $r=.41$ for economics (Kuhn et al. 2014). However, correlations between the two components of teachers' professional knowledge are plausible. There is empirical evidence that prospective teachers who have deficits in CK struggle at teaching activities, such as providing explanations, identifying students' misconceptions, or choosing and implementing appropriate tasks (Halim and Meerah 2002; Thanheiser 2009; Sullivan et al. 2010, 2013). Thus, CK is a necessary precondition for the development and application of PCK. In contrast, it seems that focusing only on CK is not sufficient for cognitive activating teaching (Baumert et al. 2010), and it is unlikely that isolated efforts in the subject foster PCK (Sullivan et al. 2013). Hence, there is a consensus that CK is necessary but not sufficient for teachers' PCK development and - in the long-term - for teaching quality (Baumert et al. 2010; Sullivan et al. 2013).

\section{OTL and the development of teachers' CK and PCK}

Research concerning OTL effects on the development of teachers' domain-specific knowledge (CK and PCK) is currently growing but still scarce (Cochran-Smith 2005; Kleickmann et al. 2013). With regard to the development of prospective teachers' CK and PCK, there is empirical evidence that CK, as well as PCK, improve during both phases of initial teacher training (e.g., Blömeke et al. 2008a; Schmelzing et al. 2013). 
These findings suggest that university-based lectures and seminars on content and content-related didactics have an impact on the development of prospective teachers' $\mathrm{CK}$ and PCK. The findings from the German COACTIV project support this assumption. Based on a cross-sectional study (Kleickmann et al. 2013), the CK and PCK of four groups in different phases of teacher training (spanning first-semester students to experienced teachers) were compared. The results indicated that OTL during the initial teacher training foster the development of CK and PCK, and university education contributes especially to the development of CK. The results also showed that prospective academic-track teachers ${ }^{\mathrm{b}}$, who have more OTL during their university-based phase, develop further in CK than prospective non-academic-track teachers during university education. In addition, it seems that formal teacher training is more important than teachers' experience. A comparison of experienced teachers and prospective teachers at the end of their initial teacher training revealed no significant differences in CK and only small effects in PCK (Kleickmann et al. 2013).

The TEDS-M study ("Teacher Education and Development Study in Mathematics"; see Blömeke et al. 2012) examined the effectiveness of primary teacher training in mathematics by comparing the teacher training systems of fifteen countries and assessing prospective teachers' mathematical CK and PCK at the end of their initial teacher training. The effects of subject-related OTL, as well as of background characteristics of prospective teachers' mathematical CK and PCK, were analysed. Significant differences in prospective teachers' $\mathrm{CK}$ and PCK in mathematics were found between different countries, supporting the assumption that OTL are crucial for the development of teachers' knowledge. In particular, OTL in mathematics have a direct influence on both prospective teachers' CK and PCK. However, OTL in mathematics didactics have only an indirect impact on prospective teachers' CK and PCK (Blömeke et al. 2012). Other studies in the German context replicated the direct predictive power of time on task (i.e., amount of time spent on subject matter courses) for the development of CK (Riese and Reinhold 2012; Blömeke et al. 2010) and PCK (Blömeke et al. 2010). Furthermore, for the domain of physical science Riese and Reinhold (2012) found a significant positive direct impact of the amount of time spent on courses in physical science didactics on prospective teachers' PCK. For the domain of business and economic education the ILLEV project ("Innovative teach-study-network in academic higher education", see Zlatkin-Troitschanskaia et al. 2013) reported similar strong evidence for the impact of university education on PCK. Kuhn et al. (2014) found that the number of hours spent on courses in business didactics significantly affects prospective teachers' PCK. Findings from our research group (Seifried and Wuttke 2010; Türling 2014; Wuttke and Seifried 2013) suggest that teacher training at least partly fosters the development of PCK in the domain of accounting. The results are based on a cross-sectional study (prospective teachers in the first and second phase of teacher training, as well as experienced teachers). Prospective teachers show a significantly lower level of competence in indicating student errors, as well as giving high-quality feedback in error situations compared with experienced teachers. However, when focusing on university-based teacher training, for the majority of the tested competence facets, no significant differences were found between prospective teachers at the bachelor's and master's levels.

Taken together, OTL during the initial teacher training (university education and school-based practical training) seem to affect the development of prospective teachers' 
CK and - at least partly of - PCK. Based on this background, the following section outlines the differences between university-based vocational teacher training in Germany and Austria.

\section{Vocational teacher training in Germany and Austria}

Germany: a step-by-step approach with two consecutive phases of teacher training

The German initial vocational teacher training consists of two phases. The first one is university-based with a clear focus on a theoretical education at both bachelor's and master's level (see below). The second phase (18-24 months, depending on federal state regulations) starts after graduation from university and takes place at teacher training institutes (Studienseminare) and schools with a clear focus on practical training. In most federal states of Germany, a prerequisite for entering the second phase is the completion of a 12-month practical business experience, gained by working for companies.

In Germany, 28 universities offer a study programme in business and economic education, which includes a six-semester bachelor's and four-semester master's programme. The programmes comprise courses in business, economics, and educational science, with a focus on vocational education and training (VET), and depending on the students' choice - a second teaching subject (e.g., mathematics, business informatics, or languages). In general, student teachers without a second subject have to pass more business and economics CK courses than those with a second teaching subject. Although each university offers courses in general pedagogy and teaching methodology, the number of subject-specific didactic courses varies across universities. Only half of the 28 universities offer courses in business or economics didactics; of those, only four teach (financial) accounting didactics in the bachelor's or master's programme (obligatory courses at three of those universities). Aside from the university coursework, prospective teachers have to pass several practical internships completed at schools. The form and duration of those internships differ between universities (Bouley 2013).

\section{Austria: an integrated model of teacher training for vocational schools}

In Austria, four universities offer teacher training programmes in the field of business and economic education. At three of them, the teacher training takes place within a five-semester master'a programme; at the remaining university, prospective teachers complete a diploma programme that lasts nine semesters, i.e., a basic phase of four semesters and an advanced phase of five semesters (for an overview of the course structure at the four Austrian universities, see Aff et al. 2008). To apply for a master's programme, a bachelor's degree in business and/or economics is obligatory. As teacher training in Austria follows a one-phase approach, universities are responsible for the practical training as well, even if this is usually done by teaching practitioners. Theoretical and practical phases alternate, with the intention of closely combining theoretical and practical knowledge. After leaving university and before starting to teach, the prospective teachers have to gain practical business experience by working for a company for two years. Furthermore, each university offers at least one lecture in (financial) accounting didactics. Austrian prospective teachers do not study a second general subject, so they spend more time on business subjects. Furthermore, the universities of Graz and 
Vienna carry out entrance examinations that test prospective teachers' CK in accounting.

In summary, the OTL during university teacher training are not distributed equally across both countries. Because of the higher amount of practical teaching experiences occurring during university teacher education in Austria and because - in contrast to Germany - all Austrian universities provide OTL in accounting didactics, it can be assumed that prospective teachers in Austria would perform better in PCK than their counterparts in Germany. With regard to CK, for the German universities, we can differentiate between prospective teachers with a major in business and economics and prospective teachers with a second teaching subject from general education. The first group seems to be - more or less - comparable with their counterparts from Austria; the second group is expected to have less CK in accounting. In Table 1, the German and Austrian teacher training systems are compared.

\section{OTL prior to university: vocational education at full-time or part-time vocational schools}

In Germany, the main pathway to the labour market (and generally the only one highly accepted by companies) is an apprenticeship in the dual system. In contrast, the qualification in full-time vocational schools is widely accepted in the Austrian labour market and enables the acquisition of hybrid qualifications: students simultaneously gain vocational training and a university entrance qualification. Thus, this educational track is very popular (Aff 2006; Deissinger et al. 2011), and the number of prospective teachers who completed a commercial apprenticeship in the German sample exceeds the one in the Austrian sample (see Table 2 below). Besides this, the curricula show that accounting topics have a higher relevance in Austrian than in German full-time vocational schools. While only a basic introduction to accounting is given in Germany, accounting is a crucial part of the school leaving examination in Austria. Therefore, it is plausible to assume that attending full-time vocational schools (e.g., commercial high schools) in Austria leads to higher levels of CK in accounting than in German vocational schools.

Table 1 Description of teacher training in Germany and Austria

\begin{tabular}{|c|c|c|}
\hline & Germany ( $n=28$ universities) & $\begin{array}{l}\text { Austria }(n=4 \\
\text { universities) }\end{array}$ \\
\hline \multirow{3}{*}{$\begin{array}{l}\text { Degree structure and educational } \\
\text { institution }\end{array}$} & consecutive approach & integrated approach \\
\hline & (1) university & $\begin{array}{l}\text { (1) university and } \\
\text { schools }\end{array}$ \\
\hline & $\begin{array}{l}\text { (2) teacher training institutions and } \\
\text { schools }\end{array}$ & \\
\hline \multicolumn{3}{|l|}{ Structure of academic teacher training } \\
\hline Degree & master & master/diploma \\
\hline Duration (semester) & four & five \\
\hline Internship in school & obligatory & obligatory \\
\hline Second teaching subject & $\begin{array}{l}\text { optional (choice among different } \\
\text { subjects) }\end{array}$ & none \\
\hline \multicolumn{3}{|l|}{ OTL in PCK at university level } \\
\hline $\begin{array}{l}\text { Universities offering courses in accounting } \\
\text { didactics }\end{array}$ & $4 / 28$ & $4 / 4$ \\
\hline
\end{tabular}




\section{Research questions}

The aim of this article is to analyse the differences between the test performance (person parameters) of prospective teachers at Austrian and German universities, considering the different teacher training systems. We focus on the following two research questions:

1. Do prospective teachers at Austrian and German universities differ in terms of their CK and PCK?

As the results from teacher effectiveness research show that OTL affect CK and PCK, and as prospective teachers at Austrian universities - in general - have more OTL during teacher education, it can be assumed that prospective teachers at Austrian universities outperform their German counterparts with regard to CK and PCK.

a) Impact of cross-country differences in teacher training on the development of CK. It is assumed that prospective teachers in Austria have higher CK test scores (person parameters), compared with those from German universities (H1).

b) Impact of cross-country differences in teacher training on the development of PCK. Prospective teachers at Austrian universities would perform better on PCK (person parameters), compared with those from German universities $(H 2)$.

2. To what extent do OTL prior to university and OTL at the university level affect the development of $\mathrm{CK}$ and PCK of prospective teachers from German and Austrian universities?

As outlined above we assume that in both countries, OTL prior to university, as well as during university education, play an important role in the development of $\mathrm{CK}$ and PCK (H3). More specifically, in the case of CK, we expect that OTL in accounting affect the development of CK. It is also plausible that OTL in accounting didactics positively influence CK, since prospective teachers have to apply their CK in those courses. Furthermore, as CK is a necessary precondition for the development of PCK, we expect that PCK is significantly influenced by OTL in accounting and business didactics, as well as by OTL in accounting. Since the OTL prior to university only cover accounting topics, we expect that these OTL have stronger impact on CK than on PCK.

\section{Method}

\section{Sample characteristics}

The total sample includes prospective teachers in a bachelor's or master's programme for business and economic education from 24 German universities $(n=1,152)$ and prospective teachers in a master's or diploma programme from four universities in Austria $(n=249)$. Data were collected between November 2013 and May 2014. At some universities, the survey took place during a regular class, while others offered separate slots for testing. Participation was voluntary. The sample size between universities ranged from 4-148 participants. Since a comparison at institutional level is not intended, this is not problematic. However, it means that some analyses - e.g. multilevel analyses with the use of the university level - are not applicable. 
Table 2 Descriptive data for the sample of prospective teachers

\begin{tabular}{|c|c|c|c|c|}
\hline \multirow{2}{*}{$\begin{array}{l}\text { Variables } \\
\text { Level of university education* }\end{array}$} & \multicolumn{2}{|c|}{ Germany $(n=1.152)$} & \multicolumn{2}{|l|}{ Austria $(n=249)$} \\
\hline & $\begin{array}{l}\text { Bachelor's } \\
(n=590)\end{array}$ & $\begin{array}{l}\text { Master's } \\
(n=552)\end{array}$ & $\begin{array}{l}\text { Diploma }<5 \text { th } \\
\text { semester }(n=37)\end{array}$ & $\begin{array}{l}\text { Master }(n=144) \\
\text { and diploma } \geq 5 \text { th } \\
\text { semester }(n=62)\end{array}$ \\
\hline Age M (SD) & $23.55(3.12)$ & $26.21(3.4)$ & $24.73(6.70)$ & $27.50(5.98)$ \\
\hline $\begin{array}{l}\text { High school GPA M (SD) } \\
\text { (1 to } 4 ; 1 \text { best grade })^{* *}\end{array}$ & $2.35(0.54)$ & $2.33(0.53)$ & $2.20(0.80)$ & $1.89(0.70)$ \\
\hline Sex female & $64 \%$ & $67 \%$ & $76 \%$ & $70 \%$ \\
\hline \multicolumn{5}{|c|}{ OTL outside of university education (Dummy variables) } \\
\hline Commercial educational background & $63 \%$ & $71 \%$ & $84 \%$ & $74 \%$ \\
\hline $\begin{array}{l}\text { Commercial high school } \\
\text { (Germany: Abitur; Austria: Matura) }\end{array}$ & $40 \%$ & $42 \%$ & $71 \%$ & $73 \%$ \\
\hline Commercial apprenticeship & $41 \%$ & $54 \%$ & $24 \%$ & $4 \%$ \\
\hline Internship in accounting & $13 \%$ & $14 \%$ & $30 \%$ & $31 \%$ \\
\hline Internship in school & $27 \%$ & $82 \%$ & $8 \%$ & $57 \%$ \\
\hline \multicolumn{5}{|c|}{ OTL during university education (Dummy variables) } \\
\hline $\begin{array}{l}\text { Specialisation in business } \\
\text { (no second teaching subject) }\end{array}$ & $36 \%$ & $39 \%$ & $100 \%$ & $100 \%$ \\
\hline Courses in business didactics & $19 \%$ & $41 \%$ & $30 \%$ & $69 \%$ \\
\hline Courses in accounting didactics & $5 \%$ & $12 \%$ & $38 \%$ & $68 \%$ \\
\hline \multicolumn{5}{|l|}{ Major in accounting*** } \\
\hline Bachelor-level & $10 \%$ & $8 \%$ & $35 \%$ & $17 \%$ \\
\hline Master-level & - & $8 \%$ & - & $13 \%$ \\
\hline
\end{tabular}

Note. *Level of university education: 10 missing observations in Germany and 6 missing observations in Austria. **German GPA = grade point average of all courses; Austrian GPA = grade point average of main courses (Mathematics, German, Foreign Language, and if a commercial high school was attended - Accounting).

***Prospective teachers with a major in accounting attended additional courses in accounting beyond the obligatory accounting courses.

Prospective teachers in Germany and Austria differed with regard to their OTL before starting university education (Table 2). In Austria, about $70 \%$ of prospective teachers had completed a commercial high school, e.g., a commercial academy (Handelswakademie), compared to about $40 \%$ in Germany. Regarding university education, prospective teachers differed especially with regard to their attended courses in accounting didactics. At the master's level, $68 \%$ of prospective teachers in Austria had completed such a course compared to only $12 \%$ of prospective teachers in Germany.

\section{Instrument to measure CK and PCK}

The items of the test measuring CK and PCK relate to a three-dimensional domainspecific model (Figure 1) and cover: (1) different content areas, (2) different facets of PCK, and (3) item difficulty. The dotted line indicates the dimensions relevant to CK items, while the solid line indicates those relevant to PCK items (for more details, see Mindnich et al. 2013; Berger et al. 2015 in press).

ad (1): To learn more about the demands of prospective teachers' fields of activity, central content areas in the domain of accounting have been identified. To do this, first the curricula of different full-time commercial schools (represented in all German federal states) and (the most popular) commercial apprenticeship tracks, as well as widely used textbooks were analysed. Secondly, experts were asked to evaluate the importance of the different contents for a deep understanding of accounting. Based on 


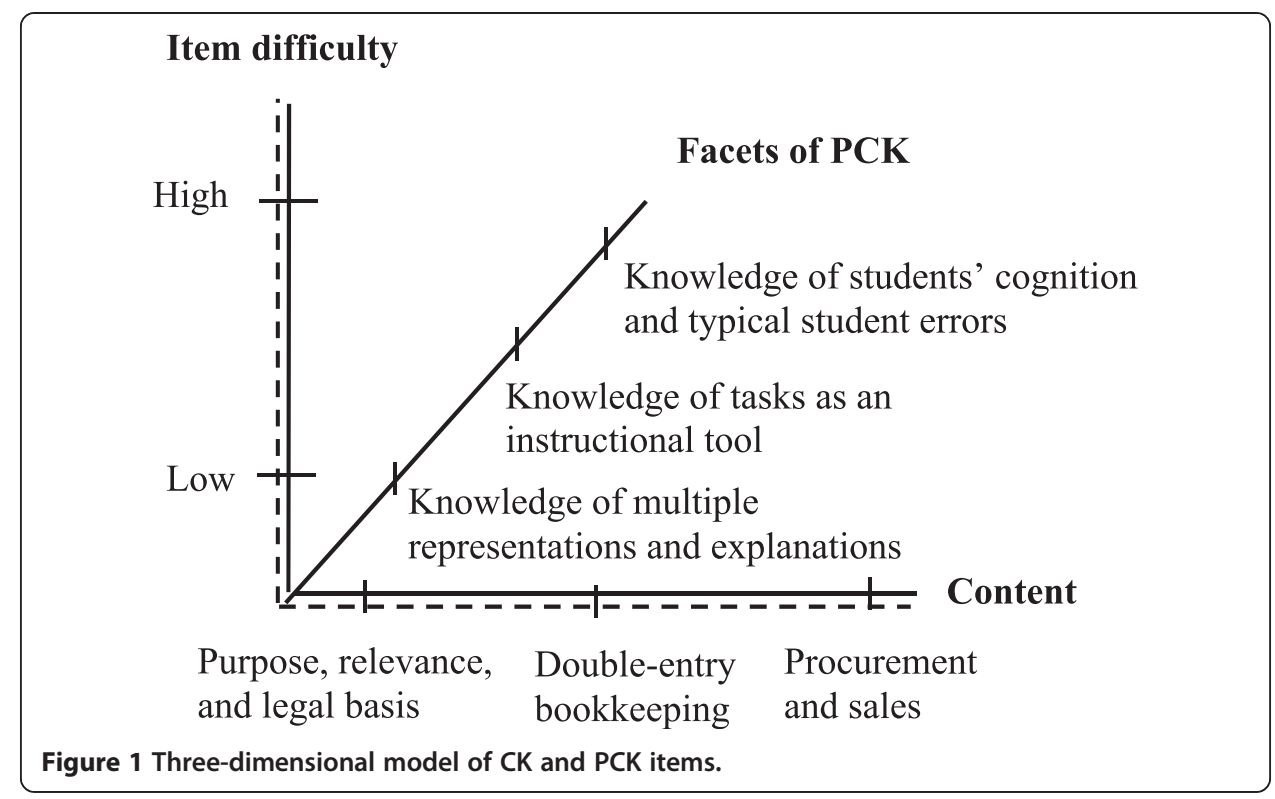

this, three areas were selected, namely: (1) purpose, relevance, and legal basis of accounting, (2) system of double-entry bookkeeping, and (3) procurement and sales (including the system of Value Added Tax).

ad (2): With regard to PCK we draw on conceptualisations from various studies (see above; Berger et al. 2015 in press). Our PCK items cover three competence facets which are particularly relevant for the quality of accounting lessons: (1) knowledge of students' cognition and typical student errors (12 items), (2) knowledge of tasks as an instructional tool (12 items), and (3) knowledge of multiple representations and explanations (12 items).

ad (3): Two levels of item difficulty were classified using Anderson and Krathwohls' (2001) taxonomy levels, accounting task characteristics (e.g., number and type of accounts), and empirical item difficulty, based on information provided by pre-tests (see Berger et al. 2013).

In total, 49 items (13 CK items, 36 PCK items) were used. The distribution of the items among the dimensions of the test instrument is shown in Table 3. Thus, every cell of the three-dimensional model (Figure 1$)$ is represented by two items $(2 \times 6 \mathrm{CK}$ items; $2 \times 18$ PCK items; plus one CK item because of booklet design constraints, see below). An example of a test item is documented in endnote " $c$ ". Open-ended, as well as close-ended, items were used. Based on the booklet design, each teacher candidate had 40 minutes to work on 28 items without using aids and appliances (such as pocket calculators). Furthermore, the participants were asked to answer a questionnaire about biographic data, which included OTL, school career, and academic track. Prospective teachers' beliefs and self-regulation skills were also measured but will not be examined further in this paper. To implement enough items to cover the model (Figure 1) and because of time constraints, a booklet design (Youden Squares) with seven test booklets was used (Frey et al. 2009). Every test booklet consists of four clusters, including seven items each.

Before implementing the instrument in Austria, the test items were adapted to local particularities by Austrian experts in business education from the University of Vienna. 
Table 3 Distribution of test items

\begin{tabular}{|c|c|c|}
\hline & CK (13 Items) & PCK (36 Items) \\
\hline \multicolumn{3}{|l|}{ Format } \\
\hline Close-ended items & 12 & 23 \\
\hline Open-ended items & 1 & 13 \\
\hline \multicolumn{3}{|l|}{ Content } \\
\hline Purpose, relevance, and legal basis of accounting & 4 & 12 \\
\hline Double-entry bookkeeping & 5 & 12 \\
\hline Procurement and sales & 4 & 12 \\
\hline \multicolumn{3}{|l|}{ Facets of $P C K$} \\
\hline Knowledge of students' cognition and typical student errors & - & 12 \\
\hline Knowledge of tasks as an instructional tool & - & 12 \\
\hline Knowledge of multiple representations and explanations & - & 12 \\
\hline
\end{tabular}

The system of double-entry bookkeeping is comparable in both countries. However, some linguistic (e.g., name of accounts) and legal differences (e.g., different tax rates) have to be considered, as well as adaptions concerning the setting (e.g., school type, names, and so on) were needed. In total, 16 test items were modified. The majority of the test items (33 items) is used in the same way in the German and Austrian test versions.

\section{Test quality}

Initially 200 items were developed, pre-tested three times and adapted to ensure item quality. For validation purposes, experts evaluated the test items regarding their appropriateness and relevance for accounting lessons. Furthermore, the think aloud method was used to learn more about task solving processes. After conducting the test, respondents' answers were coded by trained raters following a coding manual. About $10 \%$ of the open-ended questions were coded by two independent raters with substantial interrater agreement $(0.6 \leq \kappa \geq 1.0$; Landis and Koch 1977). Items with no response as well as missing by design are coded as missing. Furthermore, we used plausible values as person parameter estimates (see section below). Various analyses focusing on item fit and model fit were conducted to evaluate the material. The results provide evidence of a satisfying test quality (see Bouley et al. 2015 in press, Schnick-Vollmer et al. 2015). These analyses are based on dichotomously scored items from the first coding process. For this paper, we use a more elaborated approach by coding some of the items polytomously. Therefore, a unidimensional (1PL) latent trait model for polytomously scored values (Rasch partial credit model, Masters 1982) was used. The analyses are carried out using the software R (Version 3.1.1, package TAM, Kiefer et al. 2013).

\section{Item calibration}

The polytomous scoring of the item responses drew on theoretical considerations concerning the requirements of an item, as well as statistical parameters (especially the point-biserial index for discrimination for each category of an item, based on the German sample). In the final version, $13 \mathrm{CK}$ items consist of six 3-point items, three 2-point, and four dichotomous items. The 36 PCK items include one 4-point item, 16 3-point items, 12 2-point items, and seven dichotomous items. The item fit is evaluated 
based on the infit (weighted mean square), where values near 1 are desirable (OECD 2012). With regard to $C K$, the empirical values are $0.92 \leq$ infit $\leq 1.05$ (Austria: $0.90 \leq$ infit $\leq 1.10$ ) and for PCK $0.94 \leq$ infit $\leq 1.09$ (Austria: $0.99 \leq$ infit $\leq 1.00$ ). Hence, the item fit index for all 49 items is satisfying and provides evidence for the comparability of the items to the Rasch model (Bond and Fox 2007).

\section{Construct dimensionality}

Based on the theoretical construction, three different models are compared. All three models are estimated using stochastic integration with 4,000 nodes. The stop criterion of the algorithm was a deviance change $<0.01$. Table 4 shows the values for the unidimensional model, the two-dimensional model (CK and PCK), and the four-dimensional model (CK and the three facets of PCK). The results show that the two-dimensional model fits the data best. The estimated difference (unidimensional model compared with two-dimensional model) between the deviance-values of 96.58 is significant $(\mathrm{df}=2, \mathrm{p}<$ 0.001; Austria: $\chi^{2}=16.89, \mathrm{df}=2 ; \mathrm{p}<0.001$ ). The deviance of the four-dimensional model is lower regarding the two-dimensional model, but not significantly lower.

\section{Measurement invariance}

A comparison between German and Austrian prospective teachers requires a similar level of relative item difficulty to ensure that the test measures the same latent trait. Both the CK and the PCK test were significantly easier for the Austrian sample (mean item difficulty for CK: -1.17 ; PCK: -0.29 ) than for the Germany one (mean item difficulty for CK: -0.26 ; PCK: -0.08). Although this is in line with assumptions (see above), comparing country-specific item parameters ("delta" parameters corrected by the mean value) revealed that part of this effect seems to be caused by differential item functioning (DIF) within PCK items and especially within CK items. For about $43 \%$ of the item thresholds of the CK test and 35\% of the thresholds of the PCK test, there was a significant difference between the German and Austrian samples. ${ }^{\mathrm{d}}$ However, this result is acceptable for the following reasons: (1) The DIF effects exist in two directions. There are items that are easier for the German sample, and items benefitting prospective teachers from Austrian universities. (2) The misfit of the items is theoretically plausible. For example, the three items with especially high relative difference in the item parameters (centered item difficulty Austria $_{\text {minus centered item difficulty }}$ Germany $>1.0$ ) cover basic booking transactions, which prospective teachers at Austrian universities - unlike their counterparts in Germany - practice at several stages of their university education.

Table 4 Model comparison

\begin{tabular}{llllll}
\hline & Parameter & Deviance & AIC & BIC & CAIC \\
\hline Germany & & & & & \\
1-Dim & 112 & $64,716.07$ & $64,940.07$ & $65,505.59$ & $65,617.59$ \\
2-Dim & 114 & $64,619.49$ & $64,847.49$ & $65,423.11$ & $65,537.11$ \\
4-Dim & 121 & $64,614.53$ & $64,856.53$ & $65,467.49$ & $65,588.49$ \\
Austria & & & & & \\
1-Dim & 112 & $13,044.56$ & $13,268.56$ & $13,662.51$ & $13,774.51$ \\
2-Dim & 114 & $13,027.66$ & $13,255.66$ & $13,656.65$ & $13,770.65$ \\
4-Dim & 121 & $13,027.37$ & $13,269.37$ & $13,694.98$ & $13,815.98$ \\
\hline
\end{tabular}

Note. AIC (Akaike's information criterion); BIC (Bayesian information criterion); CAIC (consistent AIC). 
Following the procedure used in studies like PISA or PIAAC (OECD 2012; 2013), those item parameters that showed no significant difference for the German and Austrian sample were constrained to be equal for both groups. As the test was primarily developed for prospective teachers at German universities, the Austrian item parameters are estimated again with fixed item parameters according to the values of Germany for those item parameters with no significant logit difference. This procedure leads to the estimation of Austrian-specific item parameters for those items with significant relative difference and enables a reduction of potential bias due to deviations.

\section{Latent regression and plausible values (PVs)}

In the second step, person parameters using the plausible value technique were estimated. The use of PVs enables us to gain more accurate estimates of group-level results than we could from point estimates, e.g., WLE-estimates (von Davier et al. 2009). Following studies like PIAAC, ten PVs for each dimension (CK and PCK) were computed. The imputation model is a combination of an IRT model and a two-dimensional latent regression model (background model). Therefore, item parameters were fixed at the values generated in the first item calibration step (see above), and the latent regression model contains background variables like sex, age, and OTL (Mislevy 1991; von Davier et al. 2009; OECD 2012; 2013). Table 5 shows the EAP/PV-reliabilities. For both CK and PCK, the values are acceptable (Kline 1999). The correlation (using PVs) between CK and PCK is 0.80 for the German sample and 0.49 for the Austrian one. One possible explanation for this might be the high CK values of the Austrian sample.

\section{Data analysis}

The first research question focuses on the comparison of the mean achievement of prospective teachers at German and Austrian universities along the two dimensions CK and PCK (H1 and H2). Therefore, an independent two-sample t-test was used. The second research question focuses on the impact of OTL on prospective teachers' CK and PCK (H3). Multiple regression models were estimated with CK and PCK as the dependent variable for Germany and Austria. As a measure of CK and PCK, 10 plausible values for each dimension obtained from the population modelling were used (so each analysis was carried out 10 times). ${ }^{\mathrm{e}}$ Analyses were carried out using the software R (Version 3.1.1).

\section{Results}

\section{Country comparison of prospective teachers' person parameters}

Table 6 shows mean values and the standard deviation of prospective teachers' person parameters (PVs) in both countries for CK and PCK. On average, prospective teachers studying at Austrian universities have a CK-score of 0.89 and a PCK-score of 0.17 . With

Table 5 Reliabilities

\begin{tabular}{|c|c|c|c|c|c|}
\hline & \multirow[b]{2}{*}{$\mathrm{n}$} & \multicolumn{2}{|c|}{$\begin{array}{l}\text { EAP/PV- reliabilities with } \\
\text { background model }\end{array}$} & \multicolumn{2}{|c|}{$\begin{array}{l}\text { EAP/PV-reliabilities without } \\
\text { background model }\end{array}$} \\
\hline & & CK & PCK & CK & PCK \\
\hline Germany & 1152 & 0.79 & 0.73 & 0.68 & 0.68 \\
\hline Austria & 249 & 0.76 & 0.69 & 0.58 & 0.57 \\
\hline
\end{tabular}


Table 6 German and Austrian prospective teachers' person parameters (PVs)

\begin{tabular}{lllll}
\hline & $\begin{array}{l}\text { Austria } \\
\text { Mean (SD) }\end{array}$ & $\begin{array}{l}\text { Germany } \\
\text { Mean (SD) }\end{array}$ & $\boldsymbol{t}$-value & $\boldsymbol{d}$ \\
\hline Content knowledge & $0.886(0.586)$ & $-0.01(0.545)$ & 23.10 & 1.61 \\
Pedagogical content knowledge & $0.171(0.281)$ & $-0.00(0.303)$ & 8.22 & 0.57 \\
\hline
\end{tabular}

regard to Germany, the mean values of both latent dimensions were set to zero as a default of the IRT model carried out in the item calibration step using TAM; thus, the mean of the plausible values is approximately zero. The results (two-sample $t$-test) show that prospective teachers studying at German or Austrian universities differed significantly in their mean performance. The average CK and PCK person parameters of prospective teachers at Austrian universities were significantly higher than those of German prospective teachers. This is in line with expectations. ${ }^{\text {f }}$ The comparison of person parameters based on the master level (Germany: $n=552$; Austria: $n=206$ ) showed similar results. The differences were also significant for both latent dimensions with slightly lower effect sizes (CK: $d=1.47$ and PCK: $d=0.46)$. Furthermore, there was no significant difference between German prospective teachers at master's level who specialised in business and prospective teachers at master's level with a second teaching subject.

\section{Factors influencing prospective teachers' CK and PCK in Germany and Austria}

To analyse the influence of OTL on CK and PCK, multiple regression models were estimated. Data plots (residuals vs. fitted values, Q-Q plot, scale location plot, Cook's Distance plot) do not indicate a violation of the prerequisites for regression models (especially linearity and homoscedasticity). Furthermore, the value of the Durbin-Watson statistic is close to 2, supporting the assumption of independent errors (Field 2009). The average variance inflation factors (VIF) show no indication of multicollinearity (mean VIF $<1.2$ ), single VIF values $<1.37$ ).

Table 7 shows the results of the regression models on CK for Germany and Austria. The assumptions, that OTL outside of, as well as during, university education have an impact on prospective teachers' CK were supported by the data - this was especially true for Germany (H3). Furthermore, in both countries, the background control variables (sex and high school GPA) turn out to be influential. In Germany, there was a difference of about 0.25 logit points in favour of males (for Austria: about 0.18). In both Germany and Austria, high school GPA had a significantly positive impact on CK. With regard to OTL, in both countries, CK was significantly predicted by commercial apprenticeship and a major in accounting. However, Germany and Austria differed concerning the influence of OTL in didactics. In contrast to Germany, in Austria, CK was significantly influenced by the variable courses in business didactics, whereas in Germany, the attendance of courses in accounting didactics was important for the acquisition of CK. Furthermore, it seems that in Austria, OTL during university had a slightly greater influence on the development of CK than OTL outside of university education. On the contrary, in the German regression model, a commercial apprenticeship had the highest effect $(\beta=0.46 ; \mathrm{p}<.001)$. In the case of Germany, at least $43 \%$ of the variance in CK could be explained by the predictor variables, compared to $17 \%$ for Austria. 
Table 7 Regression models: The influence of OTL on CK (PVs)

\begin{tabular}{|c|c|c|c|c|c|c|c|c|}
\hline \multirow[b]{2}{*}{ Independent variables } & \multicolumn{4}{|c|}{ Germany } & \multicolumn{4}{|c|}{ Austria } \\
\hline & B & SE & $\beta$ & & B & SE & $\beta$ & \\
\hline \multicolumn{9}{|l|}{ Control variables } \\
\hline Sex (0 male; 1 female) & -0.25 & 0.03 & -0.22 & $* * *$ & -0.18 & 0.09 & -0.14 & * \\
\hline High School GPA ( 1 to $4 ; 1$ best grade) & -0.34 & 0.03 & -0.33 & $* * *$ & -0.19 & 0.06 & -0.24 & $* * *$ \\
\hline \multicolumn{9}{|l|}{ OTL outside of university education } \\
\hline Commercial high school (Dummy; $\left.\mathrm{n}_{G}=463 ; \mathrm{n}_{\mathrm{A}}=177\right)$ & 0.15 & 0.03 & 0.14 & $* * *$ & 0.02 & 0.11 & 0.01 & \\
\hline Commercial apprenticeship (Dummy; $\mathrm{n}_{\mathrm{G}}=535 ; \mathrm{n}_{\mathrm{A}}=18$ ) & 0.51 & 0.03 & 0.47 & $* * *$ & 0.33 & 0.16 & 0.15 & * \\
\hline Internship in accounting (Dummy; $\mathrm{n}_{\mathrm{G}}=159 ; \mathrm{n}_{\mathrm{A}}=76$ ) & 0.14 & 0.04 & 0.09 & $* * *$ & 0.15 & 0.09 & 0.12 & \\
\hline \multicolumn{9}{|l|}{ OTL during university education } \\
\hline Major in accounting (Dummy; $\mathrm{n}_{\mathrm{G}}=128 ; \mathrm{n}_{\mathrm{A}}=67$ ) & 0.18 & 0.05 & 0.10 & $* * *$ & 0.27 & 0.10 & 0.22 & ** \\
\hline $\begin{array}{l}\text { Courses in accounting didactics (Dummy; } \mathrm{n}_{\mathrm{G}}=94 ; \\
\mathrm{n}_{\mathrm{A}}=156 \text { ) }\end{array}$ & 0.20 & 0.06 & 0.10 & $* * *$ & -0.13 & 0.09 & -0.11 & \\
\hline $\begin{array}{l}\text { Courses in business didactics (Dummy; } \mathrm{n}_{\mathrm{G}}=346 \\
\mathrm{n}_{\mathrm{A}}=154 \text { ) }\end{array}$ & 0.05 & 0.03 & 0.04 & & 0.26 & 0.09 & 0.22 & ** \\
\hline$R^{2}$ (adjusted $R^{2}$ ) & \multicolumn{4}{|c|}{$0.43(0.43)$} & \multicolumn{4}{|c|}{$0.20(0.17)$} \\
\hline
\end{tabular}

Note: ${ }^{*} p<.05 ;{ }^{* *} p<.01 ;{ }^{* *} p<.001 ; B$ unstandardised regression coefficient, $\beta$ standardised regression coefficient. $\mathrm{n}_{\mathrm{G}}$ sample Germany; $\mathrm{n}_{\mathrm{A}}$ sample Austria. The table shows the rounded values.

Table 8 shows the results of the regression models on PCK. In contrast to CK, sex seems to have no substantial effect on PCK in both countries. However, similarly to CK, high school GPA turns out to influence PCK significantly in both Germany and Austria.

With regard to OTL, the results show a different pattern for Austria and Germany (H3). For Germany - in line with the assumption and similarly to the CK model OTL outside of university (i.e., commercial high school, commercial apprenticeship, and

Table 8 Regression models: The influence of OTL on PCK (PVs)

\begin{tabular}{|c|c|c|c|c|c|c|c|c|}
\hline \multirow[b]{2}{*}{ Independent variables } & \multicolumn{4}{|c|}{ Germany } & \multicolumn{4}{|c|}{ Austria } \\
\hline & $\bar{B}$ & SE & \multicolumn{2}{|l|}{$\beta$} & $\bar{B}$ & SE & \multicolumn{2}{|l|}{$\beta$} \\
\hline \multicolumn{9}{|l|}{ Control variables } \\
\hline Sex (0 male; 1 female) & -0.02 & 0.02 & -0.03 & & -0.07 & 0.05 & -0.11 & \\
\hline High School GPA ( 1 to 4 ; 1 best grade) & -0.16 & 0.02 & -0.29 & $* * *$ & -0.10 & 0.03 & -0.26 & $* * *$ \\
\hline \multicolumn{9}{|l|}{ OTL outside of university education } \\
\hline Commercial high school (Dummy; $\left.\mathrm{n}_{\mathrm{G}}=463 ; \mathrm{n}_{\mathrm{A}}=177\right)$ & 0.04 & 0.02 & 0.06 & * & 0.02 & 0.05 & 0.03 & \\
\hline Commercial apprenticeship (Dummy; $\mathrm{n}_{\mathrm{G}}=535 ; \mathrm{n}_{\mathrm{A}}=18$ ) & 0.24 & 0.02 & 0.39 & $* * *$ & -0.01 & 0.08 & -0.01 & \\
\hline Internship in accounting (Dummy; $\mathrm{n}_{\mathrm{G}}=159 ; \mathrm{n}_{\mathrm{A}}=76$ ) & 0.06 & 0.03 & 0.07 & * & 0.07 & 0.04 & 0.13 & \\
\hline Internship in school (Dummy; $\mathrm{n}_{\mathrm{G}}=614 ; \mathrm{n}_{\mathrm{A}}=123$ ) & 0.00 & 0.02 & 0.01 & & -0.07 & 0.04 & -0.14 & \\
\hline \multicolumn{9}{|l|}{ OTL during university education } \\
\hline Major in accounting (Dummy; $\mathrm{n}_{\mathrm{G}}=128 ; \mathrm{n}_{\mathrm{A}}=67$ ) & 0.08 & 0.03 & 0.08 & ** & 0.02 & 0.05 & 0.03 & \\
\hline $\begin{array}{l}\text { Courses in accounting didactics (Dummy; } \mathrm{n}_{\mathrm{G}}=94 ; \\
\mathrm{n}_{\mathrm{A}}=156 \text { ) }\end{array}$ & 0.10 & 0.04 & 0.09 & ** & -0.08 & 0.04 & -0.14 & \\
\hline $\begin{array}{l}\text { Courses in business didactics (Dummy; } n_{G}=346 ; \\
n_{A}=154 \text { ) }\end{array}$ & 0.05 & 0.02 & 0.07 & $* *$ & 0.01 & 0.05 & 0.01 & \\
\hline$R^{2}$ (adjusted $R^{2}$ ) & \multicolumn{4}{|c|}{$0.28(0.27)$} & \multicolumn{4}{|c|}{$0.15(0.11)$} \\
\hline
\end{tabular}

Note: ${ }^{*} p<.05 ;{ }^{* *} p<.01 ;{ }^{* * *} p<.001 ; B$ unstandardised regression coefficient, $\beta$ standardised regression coefficient. $\mathrm{n}_{\mathrm{G}}$ sample Germany; $\mathrm{n}_{\mathrm{A}}$ sample Austria. The table shows the rounded values. 
internship in accounting) foster PCK. Again, the predictor commercial apprenticeship turns out to be the most important predictor $(\beta=0.39 ; \mathrm{p}<.001)$. Furthermore, OTL during university education (major in accounting and courses in accounting and business didactics) are significantly influential. However, the effect sizes of each of those OTL are rather small.

In the case of Austria, the only variable that significantly influences PCK is prospective teachers' high school GPA. It seems that none of the OTL - whether outside of or during university education - have a significant impact on the PCK of prospective teachers from Austrian universities. This result is rather unexpected and contradicts our assumptions.

Surprisingly, completing an internship in a school had no influence on PCK in both countries. However, it must be noted that the values of $\mathrm{R}^{2}$ are rather low in both regressions (Austria 11\%, Germany 27\%).

\section{Discussion and conclusion}

The aim of the paper was to address structural differences in the teacher training programmes for teachers at vocational schools in Germany and Austria and to compare CK and PCK of prospective teachers at German and Austrian universities. As OTL during university-based teacher training differed between these two countries (one-phase degree structure in Austria, compared with a two-phase degree structure in Germany), and because of the important role of accounting in the commercial school education and university education (especially accounting didactics) in Austria, differences between German and Austrian prospective teachers' CK and PCK, with an advantage for Austria, were expected (see section above). Results show that prospective teachers at Austrian universities reach significantly higher scores in CK and PCK (PVs) compared with prospective teachers at German universities (H1 and H2). However, the assumptions can only be partially explained by the factors influencing prospective teachers' CK and PCK $(H 3)$.

Concerning the factors influencing $\mathrm{CK}$ - in line with the assumption and other studies (e.g., Blömeke et al. 2012, Riese and Reinhold 2012) - in both countries, the OTL in accounting (major in accounting) had a positive effect. For Germany, the regression analysis showed positive effects of OTL both outside of university (e.g., commercial high school, commercial apprenticeship, internship in accounting) and during university education (e.g., major in accounting, courses in accounting didactics) as expected. Similar to Germany, in Austria, OTL outside of university (commercial apprenticeship) and during university (major in accounting, courses in business didactics) significantly influence prospective teachers' CK. Furthermore, in Austria, OTL during university education had a slightly greater influence on prospective teachers' CK than OTL outside of university (commercial apprenticeship). This is in line with our assumptions. The differences regarding the influence of a commercial apprenticeship are plausible when keeping in mind the different values of an apprenticeship. This difference is reflected in our data: $54 \%$ of the German master's students completed an apprenticeship before starting their university education, compared with $4 \%$ in Austria.

However, initially, it is surprising that commercial high schools do not affect the CK of prospective teachers at Austrian universities, especially because in Austria, the 
subject of accounting plays a major role in commercial high schools and is part of the school exit examinations. However, the influence of commercial high schooling might be compensated during university education. In Austria, prospective teachers receive substantial training in accounting and must even pass a knowledge test in business administration as an admissions requirement at the beginning and/or in the middle of the master's programme (in Graz and Vienna). Therefore, it seems that all prospective teachers at Austrian universities have approximately the same level of CK when starting a master's programme, and thus, the commercial high school does not have a significant effect. This is supported by our data: the majority of the Austrian participants received high scores on the $\mathrm{CK}$ test $(\mathrm{M}=0.89, \mathrm{SD}=0.59)$, showing that the level of $\mathrm{CK}$ is generally quite high among Austrian prospective teachers. There is only a little variance that might be explained by differences in OTL.

Regarding PCK, the regression analysis again shows significant influences of OTL outside of university (commercial high school, commercial apprenticeship and internship in accounting) and during university education (major in accounting and courses in accounting and business didactics) for the German sample. Regarding prospective teachers in Austria, however, none of the OTL during and outside of university education had an impact on PCK. This result is surprising. Since for Germany the effects of OTL during university education are also very small and vanish if one includes CK in the regression (see Bouley et al. 2015 in press), the curricular validity of the test instrument has to be put into question. The test instrument was developed based on tasks that prospective teachers would have to complete in their job as a teacher. Hence, it is not entirely clear whether the content covered in university courses are helpful for completing the test. Again, there is only little variance $\left(\mathrm{SD}_{\text {Austria }}=0.28\right)$ that might be explained by differences in OTL. In all, the results are surprising (especially the low explained variance for Austria) but add to the ambiguous findings regarding the influence of subject-specific OTL (especially subject-specific didactics) on PCK (see section above or Blömeke et al. 2012; Riese and Reinhold 2012; Kuhn et al. 2014).

Regarding the background variables, sex turns out to be a significant predictor for CK (however, not for PCK) in both countries. This result is in line with other studies on CK and PCK of (prospective) teachers (e.g., Blömeke et al. 2012; Riese and Reinhold 2012). Furthermore, there are findings in the field of business and economics education that show a significant effect in favour of males (e.g., Schumann and Eberle 2014).

The results show a substantial positive effect of high school GPA as an indicator of general cognitive ability on CK and PCK. This is in line with findings in the domain of mathematics and natural science (e.g., Kleickmann and Anders 2013; Riese and Reinhold, 2012), but contradict results from the domain of business and economics (Kuhn et al. 2014).

Finally, additional methodological limitations need to be considered. Reduced reliability of the measurement could be due to the sample selection. Since we had a convenience sampling the sample could be biased by volunteers. In addition, OTL during university education may not have been captured thoroughly enough. Because of test constraints, only quantitative information about the courses (e.g., whether the participants took part in accounting didactics) is available. Statements with respect to the quality of these OTL cannot be made. Variables considering the quality or amount of the OTL may be able to explain PCK and CK further. With regard to PCK, the variable 
CK seems also to be a high predictor variable (see Bouley et al. 2015 in press). Concerning $\mathrm{CK}$, OTL in obligatory domain-specific courses like the basic courses in accounting are possible explanatory variables.

As the Austrian sample was included primarily to test the validity of the instrument, the Austrian results have to be interpreted with care. Especially the CK test seems to be too easy for the Austrian participants and might not cover the ability distribution of prospective teachers in Austria at best (limitation of the validity).

To sum up, prospective teachers at Austrian universities outperform their German counterparts with regard to CK and PCK. This is in line with expectations. However, the differences can only partly be explained by the factors influencing prospective teachers' CK and PCK. For the acquisition of CK it seems that OTL during (especially a major in accounting) and outside of university play a role in both countries. However, none of the OTL during university education have an impact on Austrian prospective teachers' PCK. In future research regarding OTL, it may be helpful to go into more detail: quantitative and qualitative analyses of OTL. Additional analyses will also focus on structural equation models to get further insights into the relationship between the constructs of the professional competence of prospective teachers.

\section{Endnotes}

${ }^{a}$ The joint research project (Universities of Mannheim, Frankfurt, and Darmstadt) was funded by the German Federal Ministry of Education and Research (funding code 01PK11003a-c).

${ }^{\mathrm{b}}$ Academic-track teachers are prospective teachers who are trained to teach in college-prepatory high schools (Gymnasium), whereas non-academic-track teachers are prospective teachers who are trained to teach in schools providing lower secondary education (Grades 5-10; e.g., Realschule).

${ }^{\mathrm{c}}$ Example of a test item:

Imagine you are planning a lesson about the VAT system. Your mentor remarks that students have difficulties with the calculation of percentages and struggle to differentiate between sales tax and input tax. Please name two further aspects of this topic that students typically have difficulties with.

${ }^{\mathrm{d}}$ For investigating DIF (differential item functioning), the technique described in Wilson (2005) is used. The relative item parameter estimates (for each country, the mean value of the item parameter estimates is zero) are used to examine statistically significant differences as an indication for DIF. According to Paek (2002, quoted from Wilson 2005), a significant logit difference value $>0.638$ is a huge effect, a value between 0.426 and 0.63 is an intermediate effect, and a difference value $<0.426$ is minor. With regard to CK, $75 \%$ of the significant threshold differences had a huge DIF and $25 \%$ an intermediate DIF. Regarding PCK, 70\% of the significant threshold differences had a huge DIF, 30\% an intermediate DIF, and only one had a value less than $0.426(0.409)$.

${ }^{\mathrm{e}}$ In addition, all analyses were carried out using WLE estimates. Overall, results were comparable.

fPlease note that we compared prospective teachers at the university level. While Austrian prospective teachers finish their formal teacher training at the end of their university education, German graduates enter an extensive in-service training phase 
that is often perceived as more helpful, with regard to teaching-related competency development, than university education. Thus, for a suitable comparison, the test must be administered at the end of the second phase of teacher education in Germany and at the end of the master's programme in Austria.

\section{Competing interests}

The authors declare that they have no competing interests.

\section{Authors' contributions}

All authors contributed substantially to this publication, which is based on a joint research project between the universities of Mannheim, Frankfurt, and Darmstadt. As a research team, all the authors listed above designed the study together and developed the test instruments. SF, SB, FB, and KSV carried out the data collection, as well as the data preparation. JS, EW, and BS designed the theoretical framework and the concept of the manuscript. SF carried out the statistical analysis for this manuscript with support of JS and SB. SF, SB, and FB each contributed to the theoretical framework section. SF wrote the section on the findings. SB and SF wrote the discussion section. SF, SB, JS, $\mathrm{FB}$, and EW participated in discussing the manuscript at different stages during the writing process. JS, EW, BS, and KSV were involved in revising the manuscript critically. All authors read and approved the final manuscript.

\section{Acknowledgments}

First of all, we thank both anonymous reviewers for the valuable comments and the constructive recommendations for improving our article. This article arose from the research project "Modeling and measurement of content knowledge and pedagogical content knowledge in business and economic education". It was funded by the German Federal Ministry of Education and Research (funding code 01PK11003a-c) and is part of the framework program "Modeling and measuring competencies in higher education". We thank Anja Mindnich, who contributed to the development of the test instrument and was involved in the data collection. We also thank Steffen Brandt, who supported us concerning statistical questions (especially IRT analyses). Furthermore, special thanks go to Richard Fortmüller and his research group at WU Vienna for data collection in Austria.

\section{Author details}

${ }^{1}$ Chair of Economic and Business Education II, University of Mannheim, L4,1, D-68161 Mannheim, Germany. ${ }^{2}$ Chair of Economic and Business Education, Goethe University Frankfurt, Grüneburgplatz 1, D-60323 Frankfurt, Germany.

${ }^{3}$ Institute of Psychology, Technical University Darmstadt, Alexanderstraße 10, D-64283 Darmstadt, Germany.

Received: 29 August 2014 Accepted: 15 January 2015

Published online: 08 March 2015

\section{References}

Aff J (2006) Ein Blick über den Tellerrand. Die berufliche Erstausbildung in Österreich und Deutschland. Das duale System und das "zwei-Säulen-Modell". WissenPlus (1):19-21

Aff J, Mandl D, Neuweg GH, Ostendorf A, Schurer B (2008) Die Wirtschaftspädagogik an den Universitäten Österreichs. bwp@Berufs- und Wirtschaftspädagogik - online Spezial 3

Anderson LW, Krathwohl DR (eds) (2001) A taxonomy for learning, teaching, and assessing. A revision of Bloom's Taxonomy of Educational Objectives. Longman, New York

Baumert J, Kunter M, Blum W, Brunner M, Voss T, Jordan A, Klusmann U, Krauss S, Neubrand M, Tsai Y (2010) Teachers' mathematical knowledge, cognitive activation in the classroom, and student progress. Am Educ Res J 47(1):133-180

Berger S, Fritsch S, Seifried J, Bouley F, Mindnich A, Wuttke E, Schnick-Vollmer K, Schmitz B (2013) Entwicklung eines Testinstruments zur Erfassung des fachlichen und fachdidaktischen Wissens von Studierenden der Wirtschaftspädagogik - Erste Erfahrungen und Befunde. In: Zlatkin-Troitschanskaia O, Nickolaus R, Beck K (eds) Kompetenzmodellierung und Kompetenzmessung bei Studierenden der Wirtschaftswissenschaften und der Ingenieurwissenschaften. Verlag Empirische Pädagogik, Landau, pp 93-107

Berger S, Bouley F, Fritsch S, Krille C, Seifried J, Wuttke E (2015) Fachwissen und fachdidaktisches Wissen im wirtschaftspädagogischen Studium - Entwicklung eines Testinstruments und erste empirische Befunde. In: Koch-Priewe B, Köker A, Seifried J, Wuttke E (eds) Kompetenzen von Lehramtsstudierenden und angehenden Erzieherlnnen. Klinkhardt, Bad Heilbrunn, in press

Blömeke S, Kaiser G, Lehmann R (eds) (2008a) Professionelle Kompetenz angehender Lehrerinnen und Lehrer. Wissen, Überzeugungen und Lerngelegenheiten deutscher Mathematikstudierender und -referendare; Erste Ergebnisse zur Wirksamkeit der Lehrerausbildung. Waxmann, Münster

Blömeke S, Seeber S, Lehmann R, Kaiser G, Schwarz. Björn, Felbrich A, Müller C (2008b) Messung des fachbezogenen Wissens angehender Mathematiklehrkräfte. In: Blömeke S, Kaiser G, Lehmann R (eds) Professionelle Kompetenz angehender Lehrerinnen und Lehrer. Wissen, Überzeugungen und Lerngelegenheiten deutscher Mathematikstudierender und -referendare; Erste Ergebnisse zur Wirksamkeit der Lehrerausbildung. Waxmann, Münster, pp 49-88

Blömeke S, Suhl U, Kaiser G, Felbrich A, Schmotz C, Lehmann R (2010) Lerngelegenheiten und Kompetenzerwerb angehender Mathematiklehrkräfte im internationalen Vergleich. Unterrichtswissenschaften 38(1):29-50

Blömeke S, Bremerich-Vos A, Haudeck H, Kaiser G, Nold G, Schwippert K, Willenberg H (2011) Kompetenzen von Lehramtsstudierenden in gering strukturierten Domänen. Erste Ergebnisse aus TEDS-LT, Waxmann, Münster

Blömeke S, Suhl U, Kaiser G, Döhrmann M (2012) Family background, entry selectivity and opportunities to learn: What matters in primary teacher education? An international comparison of fifteen countries. Teach Teach Educ 28(1):44-55 
Blömeke S, Zlatkin-Troitschanskaia O, Kuhn C, Fege J (2013) Modeling and measuring competencies in higher education. Tasks and challenges, vol 1. Sense Publishers, Rotterdam

Bond TG, Fox CM (2007) Applying the Rasch model: fundamental measurement in the human sciences. Lawrence Erlbaum, Mahwah, NJ

Bouley F (2013) Die Lerngelegenheiten in der Domäne Rechnungswesen und seiner Fachdidaktik im wirtschaftspädagogischen Studium an deutschen Hochschulen. Eine Analyse der Hochschulcurricula. Unveröffentlichte Masterarbeit, Goethe University, Frankfurt

Bouley F, Berger S, Fritsch S, Wuttke E, Seifried J, Schnick-Vollmer K, Schmitz B (2015) Der Einfluss von universitären und außeruniversitären Lerngelegenheiten auf das Fachwissen und fachdidaktische Wissen von angehenden Lehrkräften an kaufmännisch-berufsbildenden Schulen. Zeitschrift für Pädagogik, Beiheft 61, 100-115, in press.

Cochran-Smith M (2005) Studying teacher education: what we know and need to know. J Teach Educ 56(4):301-306. doi:10.1177/0022487105280116

Deissinger T, Heine R, Ott M (2011) The dominance of apprenticeships in the German VET system and its implications for Europeanisation: a comparative view in the context of the EQF and the European LLL strategy. J Vocat Educ Training 63(3):397-416

Field AP (2009) Discovering statistics using SPSS, 3rd. SAGE, Los Angeles

Frey A, Harting J, Rupp AA (2009) An NCME instructional module on booklet designs in large-scale assessments of student achievement: theory and practice. Educ Meas 28(3):39-53

Geddis AN (1993) Transforming subject-matter knowledge: the role of pedagogical content knowledge in learning to reflect on teaching. Int J Sci Educ 15(6):673-683

Halim L, Meerah MS (2002) Science trainee teachers' pedagogical content knowledge and its influence on physics teaching. Res Sci Tech Ed 20(2):215-225

Hattie J (2009) Visible learning. A synthesis of meta-analyses relating to achievement, Routledge, London

Hill HC, Rowan B, Ball DL (2005) Effects of teachers' mathematical knowledge for teaching on student achievement. Am Educ Res J 42(2):371-406

Jüttner M, Neuhaus BJ (2012) Development of items for a pedagogical content knowledge test based on empirical analysis of pupils' errors. Int J Sci Educ 34(7):1125-1143. doi:10.1080/09500693.2011.606511

Kiefer T, Robitzsch A, Wu M (2013) TAM (Test-Analysis Modules): An R-package website: http://cran.r-project.org/web/ packages/TAM/index.html

Kleickmann T, Anders Y (2013) Learning at university. In: Kunter M, Baumert J, Blum W, Klusmann U, Krauss S, Neubrand $M$ (eds) Cognitive activation in the mathematics classroom and professional competence of teachers. Results from the COACTIV project. Springer, New York, pp 321-332

Kleickmann T, Richter D, Kunter M, Elsner J, Besser M, Krauss S, Baumert J (2013) Teachers' content knowledge and pedagogical content knowledge: the role of structural differences in teacher education. J Teach Educ 64(1):90-106

Kline P (1999) Handbook of psychological testing, 2nd. Routledge, London, New York

Krauss S, Brunner M, Kunter M, Baumert J, Blum W, Neubrand M, Jordan A (2008) Pedagogical content knowledge and content knowledge of secondary mathematics teachers. J Educ Psych 100(3):716-725

Krauss S, Blum W, Brunner M, Neubrand M, Baumert J, Kunter M, Besser M, Elsner J (2013) Mathematics teachers' domain-specific professional knowledge: conceptualization and test construction in COACTIV. In: Kunter M, Baumert J, Blum W, Klusmann U, Krauss S, Neubrand M (eds) Cognitive activation in the mathematics classroom and professional competence of teachers. Results from the COACTIV project. Springer, New York, pp 147-174

Kuhn C, Happ R, Zlatkin-Troitschanskaia O, Beck K, Förster M, Preuße D (2014) Kompetenzentwicklung angehender Lehrkräfte im kaufmännisch-verwaltenden Bereich - Erfassung und Zusammenhänge von Fachwissen und fachdidaktischem Wissen. Z Erzieh 17(1):149-167

Kunter M, Baumert J, Blum W, Klusmann U, Krauss S, Neubrand M (eds) (2013) Cognitive activation in the mathematics classroom and professional competence of teachers. Results from the COACTIV project, vol 8. Springer, New York

Landis JR, Koch GG (1977) The measurement of observer agreement for categorical data. Biometrics 33:159-174

Lipowsky F, Rakoczy K, Pauli C, Drollinger-Vetter B, Klieme E, Reusser K (2009) Quality of geometry instruction and its short-term impact on students' understanding of the Pythagorean Theorem. Learn Instr 19(6):527-537. doi:10.1016/ j.learninstruc.2008.11.001

Marks R (1990) Pedagogical content knowledge: from a mathematical case to a modified conception. J Teach Educ 41(3):3-11

Masters GN (1982) A Rasch model for partial credit scoring. Psychometrika 47(2):149-174

Mindnich A, Berger S, Fritsch S (2013) Modellierung des fachlichen und fachdidaktischen Wissens von Lehrkräften im Rechnungswesen - Überlegungen zur Konstruktion eines Testinstruments. In: Faßhauer U, Fürstenau B, Wuttke E (eds) Jahrbuch der berufs- und wirtschaftspädagogischen Forschung 2013, 1st edn. Budrich Barbara, Opladen, pp 61-72

Mislevy RJ (1991) Randomization-based inference about latent variables from complex samples. Psychometrika 56(2):177-196

Neuweg GH (2014) Das Wissen der Wissensvermittler. Problemstellungen, Befunde und Perspektiven der Forschung zum Lehrerwissen. In: Terhart E, Bennewittz H, Rothland M (eds) Handbuch der Forschung zum Lehrerberuf, 2nd edn. Münster, Waxmann, pp 583-614

OECD (2012) PISA 2009 technical report, PISA, OECD Publishing. http://dx.doi.org/10.1787/9789264167872-en.

OECD (2013) Technical report of the Survey of Adult Skills, PIAAC, OECD Publishing. http://www.oecd.org/site/piaac/ _Technical\%20Report_170CT13.pdf.

Riese J, Reinhold P (2012) Die professionelle Kompetenz angehender Physiklehrkräfte in verschiedenen Ausbildungsformen. Empirische Hinweise für eine Verbesserung des Lehramtsstudiums. Z Erziehungswiss 15(1):111-143

Rohaan EJ, Taconis R, Jochems WM (2009) Measuring teachers' pedagogical content knowledge in primary technology education. Res Sci Tech Educ 27(3):327-338

Schmelzing S, van Driel JH, Jüttner M, Brandenbusch S, Sandman A, Neuhaus BJ (2013) Development, evaluation and validation of a paper-and-pencil test for measuring two components of biology teachers' pedagogical content knowledge concerning the "Cardiovascular system". Int J Sci Math Educ 11(6):1369-1390 
Schnick-Vollmer K, Berger S, Bouley F, Fritsch S, Schmitz B, Seifried J \& Wuttke E (2015) Modeling the competencies of prospective business and economics teachers - professional knowledge in accounting. Zeitschrift für Psychologie 223(1):24-30.

Schumann S, Eberle F (2014) Ökonomische Kompetenzen von Lernenden am Ende der Sekundarstufe II. Z Erziehungswiss 17(S1):103-126

Seifried J (2012) Teachers' pedagogical beliefs at commercial schools_an empirical study in Germany. Account Educ 21(5):489-514

Seifried J, Wuttke E (2010) Student errors: how teachers diagnose and respond to them. Empir Res Vocat Educ Train 2(2):147-162

Shulmann LS (1986) Those who understand: knowledge growth in teaching. Educ Researcher 15(2):4-14

Sullivan P, Clarke D, Clarke BA, O'Shea H (2010) Exploring the relationship between task, teacher actions, and student learning. PNA 4:133-142

Sullivan P, Clarke D, Clarke B (2013) Teaching with tasks for effective mathematics learning, vol 9. Springer, New York

Thanheiser E (2009) Preservice elementary school teachers' conceptions of multidigit whole numbers. J Res Math Educ 40(3):251-281

Türling JM (2014) Die professionelle Fehlerkompetenz von (angehenden) Lehrkraften. Eine empirische Untersuchung im Rechnungswesenunterricht. Springer, Wiesbaden

von Davier M, Gonzalez E, Mislevy RJ (2009) What are plausible values and why are they useful? IERI Monograph Series: Issues and methodologies in Large-Scale Assessments, Vol. 2, 9-36, Retrieved from IERI website: http:// www.ierinstitute.org/fileadmin/Documents/IERI_Monograph/IERI_Monograph_Volume_02.pdf.

Wilson M (2005) Constructing measures: an item response modelling approach. Lawrence Erlbaum, Mahwah, NJ

Wuttke E, Seifried J (2013) Diagnostic competence of (prospective) teachers in vocational education. In: Beck K, Zlatkin-Troitschanskaia O (eds) From diagnostics to learning success. Proceedings in vocational education and training. Sense Publishers, Rotterdam

Zlatkin-Troitschanskaia O, Förster M, Kuhn C (2013) Modeling and measurement of university students' subject-specific competencies in the domain of business \& economics - The ILLEV Project. In: Blömeke S, Zlatkin-Troitschanskaia O, Kuhn C, Fege J (eds) Modeling and measuring competencies in higher education. Sense Publishers, Rotterdam

\section{Submit your manuscript to a SpringerOpen ${ }^{\circ}$} journal and benefit from:

- Convenient online submission

- Rigorous peer review

Immediate publication on acceptance

- Open access: articles freely available online

High visibility within the field

Retaining the copyright to your article 